\title{
Development of Assistive Devices for Blind Sprint Athletes
}

\author{
Albadi Sinulingga ${ }^{1 *}$, Novita $^{2}$, and Joni Tohap Maruli Nababan ${ }^{3}$ \\ ${ }^{123}$ Universitas Negeri Medan, Indonesia \\ *Corresponding author. Email: badisling@hotmail.com
}

\begin{abstract}
The purpose of this research is to develop a tool for sprint athletes to set the direction in implementing the training program. This study uses the research and development method of Research and Development, namely the research method used to produce certain products and to test the effectiveness of these products. The research was conducted in 3 (three) places, namely 2 (two) schools SLB-A Yapentra and SLB-A Karya Murni and 1 (one) visual blind sprint athlete NPC North Sumatra. From the results of running trials for athletes and guides after the sprint using a remote control and headset, athletes and guides are given a questionnaire and answered according to their respective understanding. Blind athletes filled out a questionnaire assisted by the research team. From the results of a broader field test of 16 blind athletes and 5 guides / coaches, it can be concluded that development of assistive devices for blind sprint athletes meets the criteria, namely $94 \%-98 \%$ can be continued. to the next stage.
\end{abstract}

Keywords: Assistive Devices, Blind Sprint Athlete

\section{INTRODUCTION}

In accordance with the background facts above, communication is one of the problems that often occurs, with the existence of assistive devices communication have been standardized so that athletes can easily remember and respond to information so that it makes it easier for athletes to make decisions, Herman (2018). Researcher's offer is a solution in the form of developing a tool to overcome the problems experienced by blind athletes in the 100-meter Sprint sport.

The problem of this research is to create "Development of Training Aid (remote control and headset) for Blind Sprint Athletes". Information and communication technology (ICT) as part of science and technology (science and technology) in general are all technologies related to collections, collection (acquisition), processing, storage, dissemination and presentation of information.

M. D. Gall (2006) Development is the process of translating design specifications into their physical form. The development domain includes a variety of variations that are applied in learning, as well as not functioning independently apart from evaluation, management, and usage. Development is the process of translating design into physical form by applying technology, both in the form of printed technology, audio visual technology, and integrated technology that will be included in the product, Anthonio Sabaruddin (2020).
In essence, technology is not only the product of science and its inventions in the form of sophisticated machines, aircraft, reactors, or other physical facilities, but also includes organizational systems, social structures and the power that pass through them. Technology is the result of the systematic application of science, as a set of empirical rationalists from various supporting components, with the intention of controlling or controlling symptoms economically, Dwiono et al (2014).

According to Daniel P. Hallahan, James M. Kauffman, and Paige C. Pullen (2009), "Legally blind people are people who have visual acuity of 20/200 or less in the better eye even with correction (eg, eyeglasses) or have a very narrow field of view such that the diameter of the subtends is widest and the angle distance is not more than 20 degrees. This definition can be stated that a blind child is someone who has 20/200 or less visual acuity in the eyes / better vision after correction (eg glasses) or have a very narrow field of vision with the widest diameter having a viewing angle of no more than 20 degrees Blindness is essentially a condition of the eye or the sense of sight because something is not functioning properly, so it has limitations and or the inability to see, Johan Cahyo et al (2012).

The research process was carried out in various ways according to the required needs, directional devices for blind athletes in sprind athletics, namely by using a series of special digital devices equipped with remote 
control and sound sensors so that the results can be immediately known. from remote control by athletes. The use of this tool is also made easy by simply pressing a button on the remote control, the blind sprind athlete is fully controlled by the driver using the remote control from the start to the finish line.

\section{METHOD}

This uses the research and development method of Research and Development, namely the research method used to produce certain products and to test the effectiveness of these products. To be able to produce certain products, research is used, namely needs analysis and to test the effectiveness of these products so that they can function in the wider community, research is needed to test the effectiveness of these products, Sugiyono (2017).

The research was conducted in 3 (three) places, namely 2 (two) schools SLB-A Yapentra and SLB-A Karya Murni and 1 (one) visual blind sprint athlete NPC North Sumatera. The research procedure for development of assistive devices for blind sprint athletes adjusts to the steps written by Sugiyono (2017). The following is an overview of the research steps:

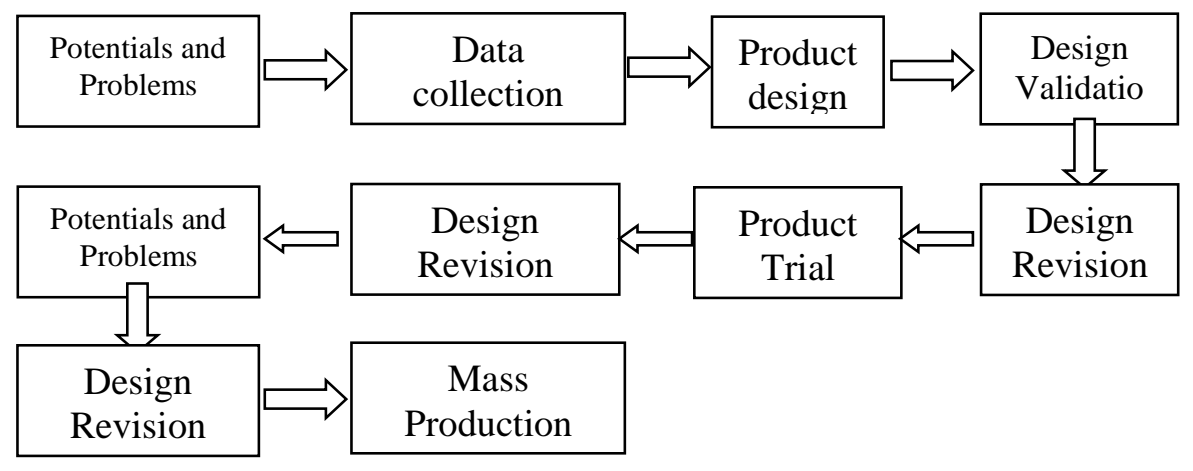

Figure 1. Method Use Steps Research \& Development (R\&D), Sugiyono (2017)

In this study, the data analysis technique used was the development of descriptive quantitative analysis techniques with percentages. This technique is used to obtain analysis of quantitative data obtained from questionnaires. The data processing formula for distributing questionnaires per test subject is as follows: A preliminary study was conducted to obtain a needs analysis.

From the observations made in the study, the researcher saw that athletes and sprint trainers / guides had problems with collaboration of motion, acceleration, and communication while doing exercises. The analysis used is descriptive analysis with the aim of knowing the needs of athletes or guides to obstacles encountered during the training process.

\section{RESULTS AND DISCUSSION}

Almost all branches are carried out manually, so any training problems both in terms of equipment and training evaluation are carried out manually, Johan Cahyo et al (2012). Now it is time to find a solution to every problem must be fast, accurate, and precise. Suliadi also explained about the purpose of sports coaching, especially for people with disabilities so that they are more independent in carrying out their daily lives, this is the principle of guidance carried out in North Sumatra.

Moreover, the problem of visually impaired from various sports which has problems that are not much different, namely very limited mobility, which makes the coach have to work hard to deal with these obstacles. Talking about equipment and overcoming problems faced by blind athletes is still done manually so that the training process is very limited. Not only blind athletes, but almost all sports with disabilities. One of the sports that is contested is the participant sprint number, one of which is blind people.

For people with visual impairments, sports can be said to be a connecting channel for quality of life. It is not easy, blind people will find it difficult to learn these techniques directly. Although learning can be done by utilizing the functioning of the senses, it is feared that if you are going to do it independently, you will also accept the risk. Professional guidance is needed by people who are competent as providers of appropriate material.

In this sprint sport, blind athletes are given more demands, Mukhamad Nurudin (2015). One example is the target given by the coach, so that sprint athletes can get the best ranking in a competition. In addition, athletes are faced with greater obstacles than other 
sports, such as the risk of falling, injury or injury during training and competing, Dwi Gansar (2016). The results of the interview by Deputy Secretary Suliadi (National Paralympic Committee) of North Sumatra stated that there are obstacles that occur to blind athletes who carry out the Intensive Training Program (PPI) athletes who are faced with greater obstacles compared to other sports, such as risks. fall, injury or injury.

Suliadi (North Sumatra Management) also has a special copy of blind athletes, that is, he hopes that blind athletes in sprinting both during training and in competitions do not use a supervisor and that is an achievement from outside, can be achieved by integrating technology during the competition. training process, so that blind sprint athletes don't run off course, and don't crash. It is indeed difficult and Suliadi said even though it is difficult but it is possible.

Preliminary research was conducted to obtain a needs analysis. From the observations made in the study, the researcher saw that athletes and sprint trainers / guides had problems with motion, acceleration, and communication while exercising. Results of interviews with NPC administrators, coaches / guides and athletes. During training, communication, collaboration and acceleration during training, and still being an obstacle during training. From needs analysis that has been carried out on 10 blind people, $90 \%$ have participated in blind sprint competitions, $90 \%$ experienced problems during sprint training, $90 \%$ experienced the same obstacles during training, $80 \%$ had never received assistance. technology. $100 \%$ they want to get the tools to overcome the obstacles they experience during training.

The analysis used is descriptive analysis with the aim of knowing the needs of athletes or guides to obstacles encountered during the training process. Based on the results of observations, interviews and needs analysis above, it can be concluded that the management, trainers / guides, especially athletes, really want to get training aids (remote control and heatset).

From the results of the small group test carried out after the expert evaluates the product that the researcher has made. The small group test was carried out on 10 athletes and guides / coaches blind sprind athletes, 3 guides / coaches, the conclusion is: From the results of small group trials on athletes and guides after the sprint using remote control and headsets, athletes and guides are given a questionnaire to fill in according to understanding each. A blind person filled out a questionnaire assisted by the research team. From the results of small trials on 10 blind athletes and 5 guides / coaches, it was concluded that development of assistive devices for blind sprint athletes met the criteria to be continued in large group trials because of the percentage of each aspect. covers $85 \%$ - $98 \%$.

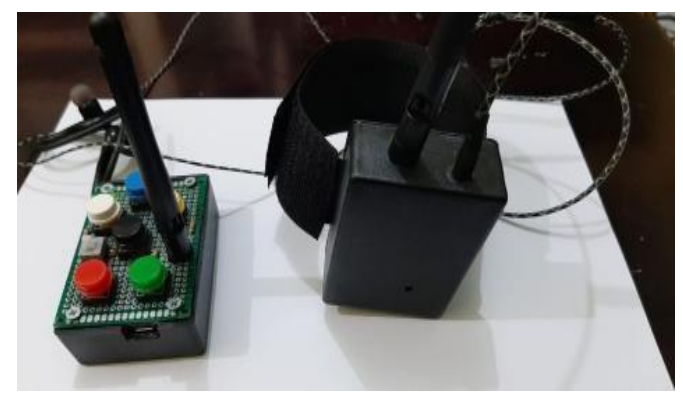

Figure 2. Remote Control and Headset

Picture 2. Remote control and headset test results, expert revision, and validation. The revisions to the results of interviews, questionnaires, and observations during the trial are as follows:

- The buttons have different colors.

- Minimize its size.

- The shape of the headset is adapted to the shape of the ear curve. Revisions and improvements did not detract from the start.

The results of the first trial stated that the product was feasible to proceed to the next stage, namely a large I wide trial by considering the advice given by the guide and athlete. prior to the improvement of the research tools, discussions with experts, to decide on input and suggestions for guides and athletes who decide on changes in weight that slightly disrupt the athlete's running training activities. then it was decided to try to lighten the product.

After discussion with the product manufacturing team, the tools were repaired so that the following results were obtained:

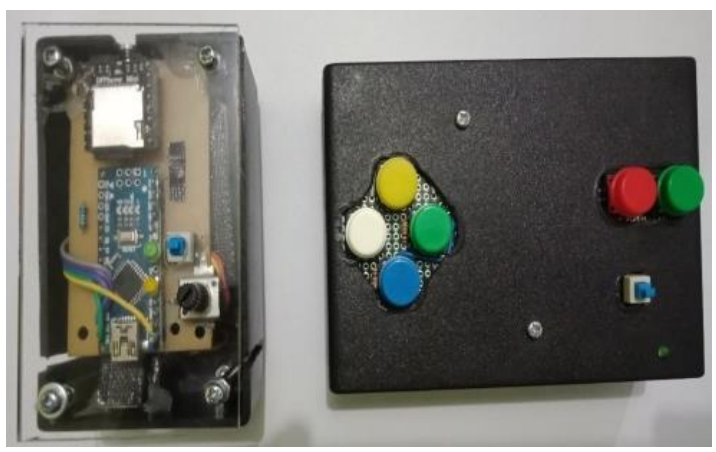

Figure 3. Initial Product 


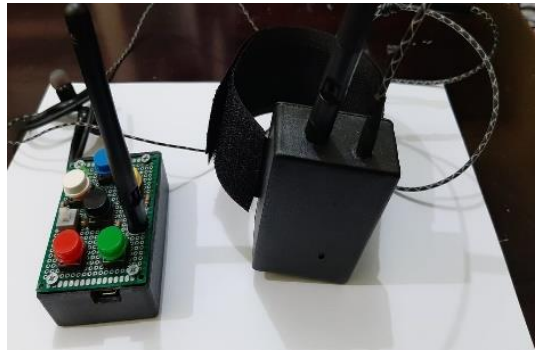

Figure 4. Product Revisions

After the finished product, the researcher takes it to the experts to re-validate the validation results of product improvement $89.33 \%-93.99 \%$. This result is higher than the initial validation and states the product is feasible to be tested.

Extensive / large trials conducted. The results of the broad / large group test of 16 blind sprint athletes showed that the blind sprint training aids (remote control and headset) had met the proper or valid criteria. The validation presentation of the questionnaire that has been distributed to the sample shows that $94 \%-96 \%$ of them admit that the training aids training aids (remote control and headset) meet the criteria. From the results of small group trials of $84 \%-96 \%$ and results of large group trials of $94 \%-96 \%$ there was a significant progress in the feasibility of the tool. So it can be concluded that the product of training development of assistive devices for blind sprint athletes meets the criteria worthy of use.

\section{CONCLUSION}

From the results of running trials for athletes and guides after the sprint using a remote control and headset, athletes and guides are given a questionnaire and answered according to their respective understanding. Blind athletes filled out a questionnaire assisted by the research team. From the results of a broader field test of 16 blind athletes and 5 guides / coaches, it can be concluded that development of assistive devices for blind sprint athletes meets the criteria, namely $94 \%$ - $98 \%$ can be continued. to the next stage.

\section{REFERENCES}

[1] Anthonio Sabaruddin, (2020). Development of Learning Pocket Books Pencak Silat Extracurricular as Junior High School Learning Resources. 1st Unimed International Conference on Sport Science (UnICoSS 2019) Volume: 23.

[2] Daniel P. Hallahan, James M. Kauffman \& Paige C. Pullen. (2009). Exceptional Learner an Introduction to Special Education. United States of America: PEARSON.

[3] Dwiono dkk. (2014). Alat Bantu Navigasi Penyandang Tunanetra Menggunakan Sensor Ping dan Buzzer di Jurnal Teknik Elektro dan Komputer, 2(1), 105-113

[4] Dwi Gansar. (2016). Pembinaan Olahraga Untuk Penyandang Disabilitas Di National Paralympic Committee Salatiga.Journal of Physical Education and Sport, 5(1), 17-23

[5] Herman. (2018) Teknologi Virtual Reality Untuk Media Informasi Kampus.Jurnal Teknologi Informasi dan Ilmu Komputer (JTIIK), 6(1), 71-76

[6] Johan Cahyo dkk. (2012). Pengaruh Latihan Lompat Kijang Terhadap Kecepatan Lari Di Journal of Sport Sciences and Fitness, 1(1), 17-21.

[7] M. D. Gall, J. P. Gall, and W. R. Borg, (2006). Educational Research: An Introduction, 8th Edition.

[8] Mukhamad Nurudin. (2015). Pengaruh Latihan Rope-Skipping Dan Box Jumps Terhadap Kemampuan Menggiring Bola Pemain SSB Di Unnes Journal of Sport Sciences, 4(1), 50-59.

[9] Sugiyono. (2017). Penelitian dan Pengembangan. Jakarta. Cipta Pustaka 